\title{
Assessment of institutional and asset-related functions in the urban water sector in Libya
}

\author{
Khaled A. Rashed \\ Associate Professor, Department of Civil Engineering, Faculty of Engineering, University of Tripoli, Tripoli, Libya
}

Email address:

k65rashed@yahoo.co.uk

\section{To cite this article:}

Khaled A. Rashed. Assessment of Institutional and Asset-Related Functions in the Urban Water Sector in Libya. Journal of Water Resources and Ocean Science. Vol. 2, No. 5, 2013, pp. 90-94. doi: 10.11648/j.wros.20130205.16

\begin{abstract}
The total urban water supply in Libya is about 600 million cubic meter per year, of which more than $90 \%$ came from groundwater. Surface water resources are minimal and Libya relies on wells, desalination and transported water for urban water supply. Transported water supply is essentially targeted towards the agricultural sector; however, the share of the urban sector has been increased to cope with increasing demand. This paper focuses on the organization of urban water sector with regards to institutional level and asset level, trying to high light the problems facing urban water sector and proposes solutions. In addition to the newly re-established Water and Wastewater Company, there are six main players in the urban water sector today that duplicate institutional and asset-based functions. Three of them deal with supply side (Desalination Company, Water Authority, and Man-made River Authority) and the other three deal with demand side (Ministry of Utilities, Project Execution Authority, and Environment Authority). After assessing the current situation of the urban water sector mainly around organizational consideration, one can conclude that in terms of institutional setup there is no clarity around supply/demand decisions. On the asset-related side, water and wastewater operations have been confused by frequent re-organizations. Apart from fragmentation, overstaffing of Water and Wastewater Company is significant, especially in light of the level of service provided to consumers. In order to build a professional urban water sector, in terms of institutional and asset-related levels, clear key functions for both levels have been proposed.
\end{abstract}

Keywords: Urban Water Supply, Institutional Functions, Asset-Related Functions

\section{Introduction}

Libya, which accommodates about 6 million people, relies on groundwater, transported water and desalination for urban water supply. Groundwater supply figure, which is based on data gathered by the Water Authority (WA) from the municipalities through field visits and interviews (no flow metering was used), is estimated to be around 282 million cubic meter per year. Transported water supply, which comes from deep aquifers in the south of Libya via the Man-Made River (MMR), is estimated to be around 286 million cubic meter per year (Rashed, 2004). Desalination supply figure, which is based on actual water deliveries made by the operators to the urban water network, is estimated to be around 35 million cubic meter per year. These three sources together provide a total of about 600 million cubic meter per year, of which more than $95 \%$ came from groundwater. These quantities of water $(600$ million cubic meter per year) are delivered to consumers through network of pipes, but the Libya's water network coverage rates are not exactly known. In order to estimate the water network coverage rates, interviews with key stakeholders and published reports lead us to an estimate of $65 \%$, based on a $70 \%$ average coverage for users living in cities and a $50 \%$ average coverage for users living in rural areas. Our estimate of $65 \%$ average coverage for Libya is in fair agreement with the World Bank estimation (World Bank, 2007), which estimates a national average of $70 \%$ for Libya and average water coverage in the Middle East and North Africa (MENA) region stands at 75\% (figure-1). According to the population density, the country can be divided into fifteen water regions. Population by water region are presented in figure-2 (GIA, 2010). Using the quantity of water provided for urban supply and the percentage of people connected to the water networks lead to an initial national daily supply per capita estimate of 420 litre. This figure of water consumption includes domestic and non-domestic consumptions and unaccounted for water. In fact there is a wide regional variation in water supply as presented in figure-3. This paper focuses on the 
organization of urban water sector with regards to institutional level and asset level, trying to highlight the

problems facing urban water sector and proposes solutions.

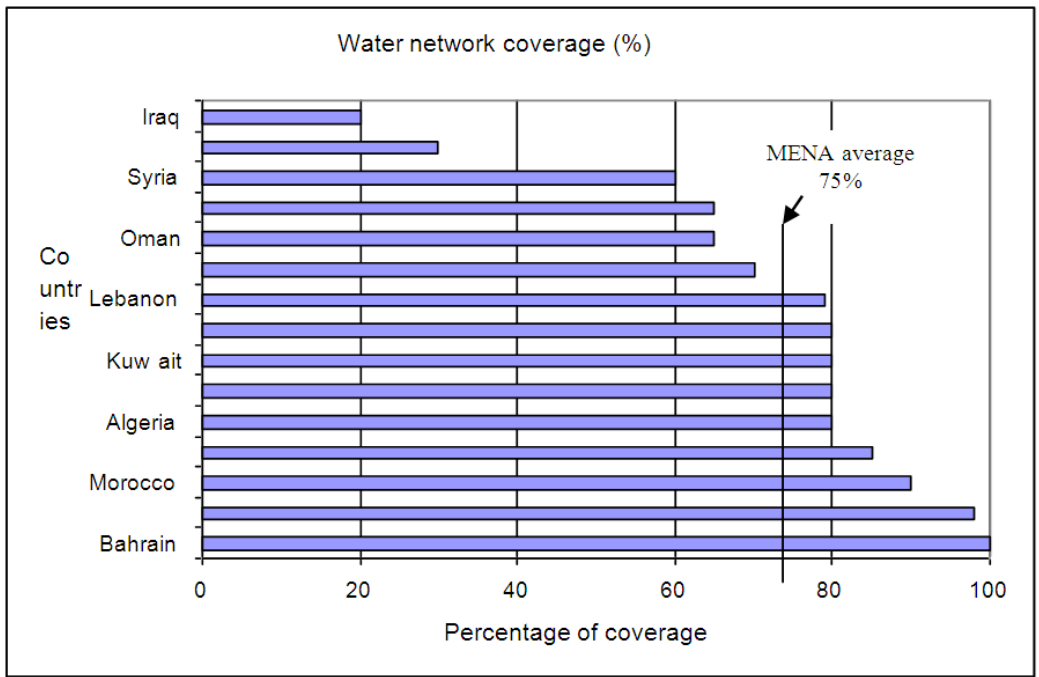

Figure-1: Water network coverage in the MENA countries

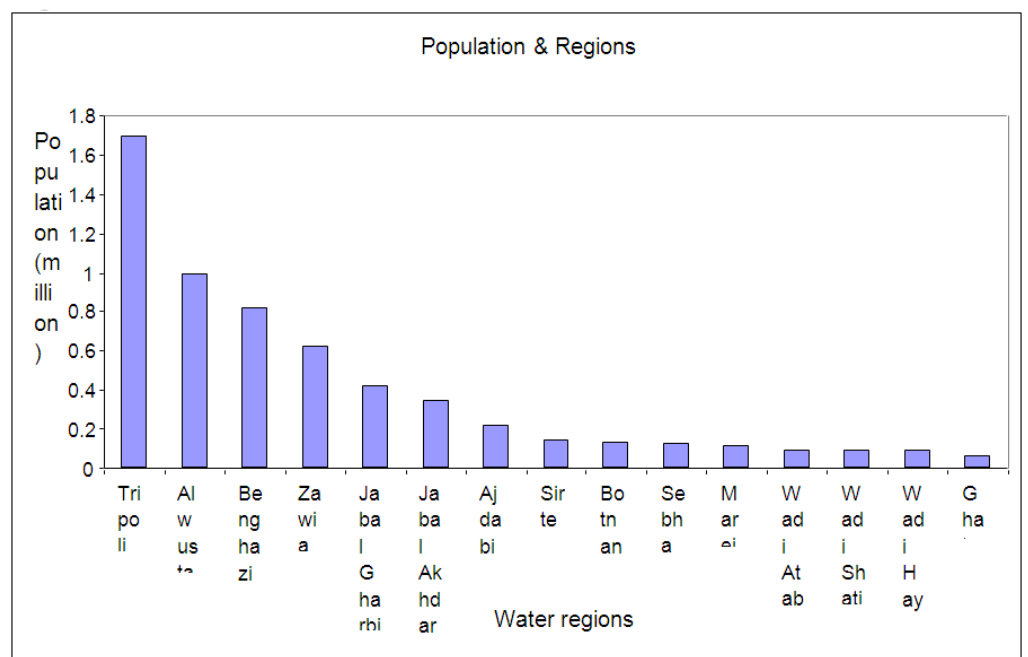

Figure-2: Population by water regions

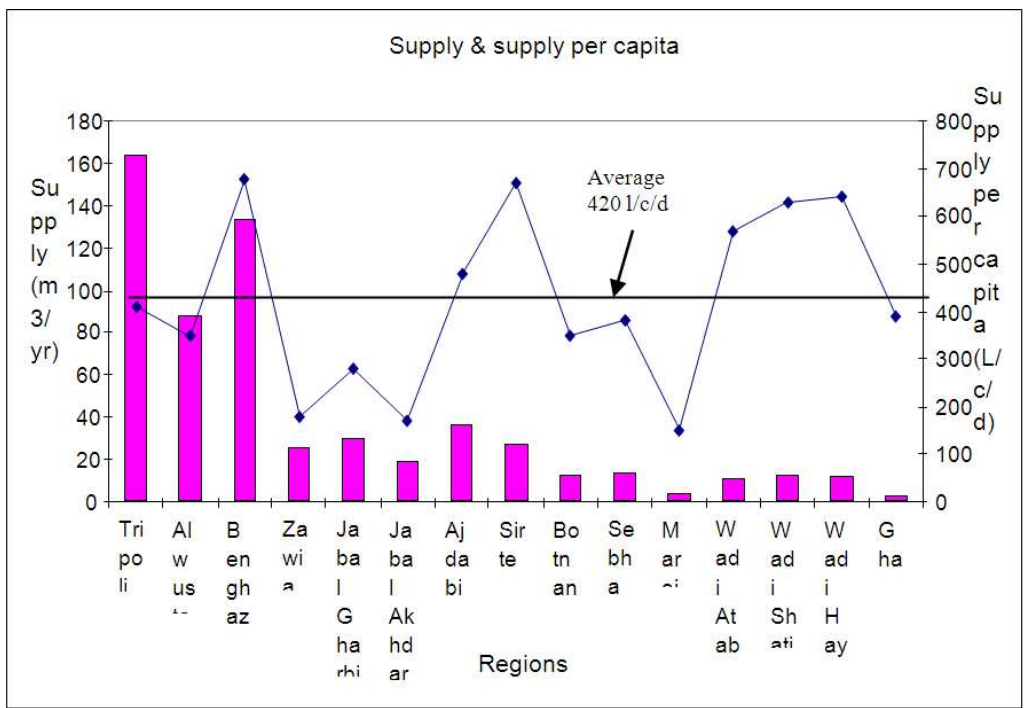

Figure-3: Regional variation in water supply Institutional functions 
In addition to the newly re-established Water and Wastewater Company, there are six main players in the urban water sector today that duplicate institutional and asset-based functions. Three of them deal with supply side and the other three deal with demand side. The Water and Wastewater Company duties are to operate water and wastewater assets; test water quality and bill and manage customers. With respect to supply side; the Desalination Company duties are to plan, operate and develop desalination plants; the Water Authority duties are to study, plan and implement ground and surface water projects as well as to recommend on groundwater exploitation and allocation; the Manmade River Authority duties are to determine the supply rates, develop and set long term strategy, identify current and forward looking demand requirements, strategic priorities, investment and benefits. With respect to demand side; the Ministry of Utilities duties are to perform urban planning of water and wastewater infrastructure and monitor water quality; the Project Execution Authority duties are to execute projects related to expansion and refurbishment of water and wastewater networks; the Environment Authority duty is to set quality standard (Rashed, 2010). Other institutional roles are not clearly allocated between entities in the sector. For examples; in terms of water resource management, water allocation between agricultural and urban sector is based on negotiations instead of a principle-driven policy (economics, environment, domestic usage); in terms of water quality control, no single effective body for ensuring legal compliance with water and wastewater legislations. Some institutional roles are not in place at all. For examples; in terms of sector regulating, tariffs set by central government, without regard to value of water to end user, production cost or demand management needs; in terms of customer service, no national authority setting standards for customer service. A key element that is missing in the institutional setup is clarity around supply/demand decisions. According to the current situation there are no clear answers to the following key questions:

1. In which order should supply sources be utilized?

2. How quickly should withdrawals from ground water resources be reduced?

3. Should all the transported water go to the Agriculture sector? Or should an increasing share feed the urban network?

4. Should water allocation be based on the value of the end product to the economy?

\section{Asset-Based Functions}

Assets can be classified into five classes; (1) Desalination plants; (2) Well pumps; (3) Storage tanks; (4) Transmission pipes; and (5) Meters (WWC, 2009). Description and performance of these assets are summarized in table-1. On the asset-related side, water and wastewater operations have been confused by frequent reorganizations. Table- 2 shows the recent changes in urban water sector, from 1998 to 2009. Apart from fragmentation, overstaffing is significant, especially in light of the level of service provided to consumers. Staff functions are unbalanced in terms of Full Time Equivalent (FTE) and do not reflect the needs of the operation. Figure-4 shows obvious surplus staff in the Water and Wastewater Company when compared with other countries (UN, 2000). In summary, water assets are in poor condition and asset functions suffer from organizational fragmentation and weak financial management.

Table-1: Assets description and performance

\begin{tabular}{|c|c|c|}
\hline Assets class & Description & Performance \\
\hline Desalination plants & $\begin{array}{l}-12 \text { desalination plants in } 8 \text { of the } \\
15 \text { regions }\end{array}$ & $\begin{array}{ll}- & \text { Low utilization rates } \\
\text { - } & \text { Network bottleneck } \\
\text { - } & \text { Geared towards electricity } \\
\text { - } & \text { Lack of spare parts }\end{array}$ \\
\hline Well pumps & $\begin{array}{l}\text { - Spread throughout the country, depending on regional needs } \\
\text { and aquifer locations } \\
\text { - } \quad 9 \text { out of } 15 \text { regions rely almost entirely on local wells for } \\
\text { supply }\end{array}$ & $\begin{array}{ll}\text { - } & \text { Ageing pumps } \\
- & \text { Poor maintenance } \\
- & \text { Frequent interruptions and shut-downs } \\
\text { - } & \text { Lack of spare parts }\end{array}$ \\
\hline Water tanks & $\begin{array}{l}\text { - Located at the outskirt of large urban areas, feeding into network - } \\
\text { Aggregate water supplies - Regulate water flow and act as buffer supply }\end{array}$ & - Old tanks - Lack of proper maintenance \\
\hline $\begin{array}{l}\text { Transmission/ } \\
\text { Distribution pipes }\end{array}$ & $\begin{array}{l}\text { - } \quad \text { Connect water tanks to consumers } \\
\text { - } \quad \text { Diameters (100 to } 1200 \mathrm{~mm}) \text { - Cast iron and galvanized steel; } \\
\text { increasing use of PPE }\end{array}$ & $\begin{array}{l}\text { - Old and requires maintenance - Leakage is poorly } \\
\text { understood }\end{array}$ \\
\hline Meters & $\begin{array}{l}\text { Visual reading } \\
\text { Low penetration }\end{array}$ & $\begin{array}{l}\text { - Low meter penetration - Require maintenance and } \\
\text { are either out of operation or not properly working }\end{array}$ \\
\hline
\end{tabular}


Table-2: Changes in urban water sector in Libya

\begin{tabular}{|c|c|c|c|c|}
\hline Years & 1998 & 2003 & 2006 & 2009 \\
\hline Scope & Water, wastewater & Water, wastewater & $\begin{array}{l}\text { Water, wastewater, } \\
\text { Garbage } \\
\text { collection, } \\
\text { Gardening }\end{array}$ & Water, wastewater \\
\hline Level & National company & 32 local companies & 32 local companies & National company \\
\hline
\end{tabular}

* Ministry of Services; ** Housing \& Utilities Corporation; *** Ministry of Utilities

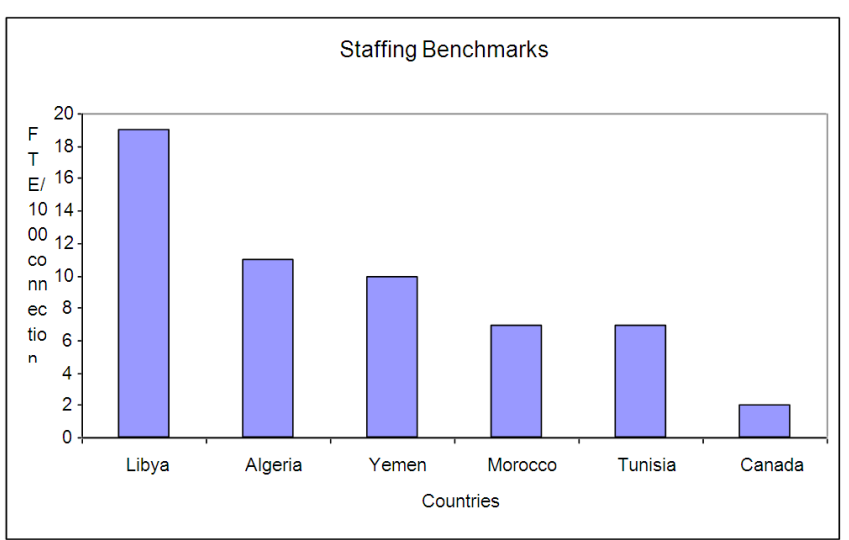

Figure-4: Water and Wastewater staffing Benchmarks

\section{Recommendations}

Typically, we would expect to see two broad functions (institutional and asset-related) in the water and wastewater sector, each with a specific set of activities;

Firstly, six key functions at institutional level can be recommended;

1- Perform Water Resource Management:

1.1- Develop long term supply/demand requirements.

1.2- Develop policies and regulations for water demand, supply allocation and sustainable development.

2- Define sector strategy:

2.1- Establish targets (service levels, and coverage).

2.2- Recommend new tariff mechanisms.

2.3- Recommend degree and form of private sector involvement.

2.4- Recommend pricing changes.

3- Regulate sector:

3.1- Ensure sector participants comply with water laws while financially viable.

3.2- Ensure that monopoly status is not abused (price caps and control over efficiency).

3.3- Define consumer standards.

4- Control water quality:

4.1- Inspect and monitor water resources.

4.2- Enforce quality standards.

5- Issue licences and manage water right:

5.1- Define terms and conditions of licenses and water rights in line with water resource management policies.
5.2- Enforce terms of licensing.

6- Address consumer complaints:

6.1- Receive user's complaints.

6.2- Pursue and investigate complaints.

Secondly, five key functions at asset-related level can be recommended;

1- Plan assets and investments:

1.1- Long-term strategic plans for new asset requirements.

1.2- Budget and authority to develop an asset strategy.

2- Finance asset development:

2.1- Water companies should not depend entirely on government funding.

2.2- Revenues should cover cost of operation.

2.3- Understanding of cost of production and operating cost.

3- Operate and maintain assets:

3.1- Network maintenance and renewal should be the responsibility of Water Company.

3.2- Engineering, operational and financial capabilities require strengthening.

4- Billing and collection:

4.1- Setting tariffs is the Water Company right.

4.2- Revenues are essential to funding company operations.

4.3- Ability to enforce bill payment.

5- Provide customer service:

5.1- Complaints are dealt with by customer service centres.

5.2- Meter for every customer so that customers can get information to reduce consumption and billing.

\section{Conclusion}

Libya (6 million people) relies on groundwater, transported water and desalination for urban water supply. These three sources provide 282 million cubic meter per year, 286 million cubic meter per year, and 35 million cubic meter per year respectively. In this paper, a comprehensive study has been conducted especially with regards to institutional and asset-related functions and activities. After assessing the current situation of urban water sector mainly around organizational consideration, one can conclude that in terms of institutional setup there is no clarity around supply/demand decisions. On the asset-related side, water and wastewater operations have been confused by frequent 
re-organizations. Apart from fragmentation, overstaffing of Water and Wastewater Company is significant, especially in light of the level of service provided to consumers. Six key functions at institutional level have been proposed and five key functions at asset-related level have been proposed.

\section{Acknowledgement}

The author would like to tank Mr. A. Elmetsho (Water and Wastewater Company) for allowing access to the company's data.

\section{References}

[1] GIA. 2010. National Statistical Book for the year 2010.

[2] Rashed, K. A. 2004. A 2045 vision for Municipal water supply in Tripoli. Proc.
[3] Symposium on Challenges Facing Water Resources Management in Arid and Semi-Arid Regions, Lebanon, October, 7-9.

[4] Rashed, K. A. 2010. Challenges facing urban water sector in Libya. Proc. BHS international hydrology symposium, UK, July, 19-23.

[5] United Nations. 2000. We the Peoples: The Role of the United Nations in the $21^{\text {st }}$

[6] Century. UN Report 10017, New York.

[7] World Bank. 2007. Making the Most of Scarcity: Accountability for Better Water Management in the Middle East and North Africa. MENA Development Report 41113, Washington, DC.

[8] WWC. 2009. Water Problems in Tripoli Municipality and Proposed Solutions: Internal Report. 